\title{
Information Model for Global Shipbuilding in the Period of 2016 - 2020
}

\author{
Vinko Vidučić
}

This study explores the worldwide demand for the newlybuilt ships from 2014 to 2017 and produces forecasts for the demands concerning the years 2018 and 2020, on the basis of mental and verbal insights into the global shipping market, theoretical aspects of the issue, and the selected variables (South Korea, China, Japan, Europe and the Rest of the World) of the information model for the global shipbuilding. The value of the variables for the year 2016 has been achieved by taking into account the synergetic effect of the percentage obtained per order books across the world, gross tonnage in 0,000 GT and the value of vessels in billion US\$ for each selected variable. In the next stage these values have been quantified based on the mental and verbal insights into the scientific aspects of the global shipping market variables of the information model for the global shipbuilding in the years of 2018 and 2020. In this way, for the first time, the growth matrix has produced the values of the

\section{KEY WORDS \\ $\sim$ Shipbuilding \\ $\sim$ Ship \\ $\sim$ Cost \\ $\sim$ Production \\ $\sim$ Growth \\ $\sim$ Shipyard \\ $\sim$ Orders \\ $\sim$ Economy \\ $\sim$ Crisis}

University of Split, Faculty of Maritime Studies, Split, Croatia

e-mail: vinko.viducic@pfst.hr

doi: 10.7225/toms.v07.n01.010

This work is licensed under (cc) BY selected variables, i.e. the direct growth rates of the information model for the global shipbuilding for the period 2018-2020. The research has involved a combination of scientific methods, among which the most relevant are analysis and synthesis, induction and deduction, descriptive, comparative, statistical and mathematical methods, method of model drawing (growth matrix), and methods of proving and refuting.

\section{INTRODUCTION}

There are presently more than 250 large shipyards in the world. Most of them operate in the East Asian countries, i.e. South Korea, China, and Japan. The importance of this industry is clearly reflected through job creation across various business sectors and the interrelation of their economic activities. One of the causes of the current economy growth in these countries is the efficiency of their shipbuilding industries.

The development of world economy under global conditions has resulted in an increased demand for the seaborne shipping capacity. This has led to the growing number of newbuilding orders. This, naturally, affects the price of newlybuilt vessels. Opposite trends occur in the times of economic crisis, when the demand for newbuilding decreases along with the price of these products.

In terms of technology, shipbuilding represents an intensive activity. It requires the application of cutting-edge technological achievements and encourages the innovative production processes that reduce costs and affect competitiveness in a significant manner.

This issue has been in the focus of numerous studies, but this is the first time that it has been approached through an information model. This study uses the growth matrix to calculate the values of the selected variables of the information model for global shipbuilding and their direct growth rates for the period 
2016 - 2020. In addition to the matrix and modelling, the study has also involved a combination of relevant scientific methods, including statistical and mathematical methods, induction and deduction, descriptive and comparative analysis and synthesis.

It is important to note that the quantification of the variables has been performed by taking into consideration the synergy of total gross tonnage and financial value of the newlybuilt ships, with reference to the countries and areas where the most important large shipyards are located.

\section{MARITIME SHIPBUILDING MARKET}

A shipbuilding process starts by designing a vessel. This implies a great deal of maps and drafts for making individual sections, as well as the design of the vessel as a whole. Designers and builders have to define and elaborate production processes, the flow of material supply, and so on. All these activities take considerable time resulting in multi-year deadlines. The latter stretches over a long period of time also due to the fact that respectable shipyards tend to keep their order books filled for a number of years ahead. In addition to deadlines, price, quality, and references, a shipper typically selects a particular shipyard taking into account the ways of financing the project (Hrvatska enciklopedija, 2017).

Shipbuilding heavily affects the growth of the related industries that create intermediate products to be fitted goods into the newbuilding. These industries include ferrous and nonferrous metallurgy, engine building, wood industry, paint and lacquer industry, electrical engineering, etc. (Šimičić, 1972).

Through these multiplier effects, a single job in the shipbuilding industry creates three to five jobs in associated industries. Modern shipyards focus on their core business, outsourcing most of other production activities. Nevertheless, shipyards - and not the subcontractors - take the ultimate responsibility for the deadlines, product quality, and for meeting all other liabilities stipulated by the contract between the shipper and the shipbuilder (Kersan-Škabić, 2009).

The value of the shipbuilding contract depends on the warranty costs, deadline, quality of the delivered product, risk of increase in material prices (especially iron), cost of insuring the newbuilding in progress, currency of payment and the related risks, price of energy, labour, and so on (Ivanković et al., 2009).

A shipyard has to ensure necessary assets for all processes during building a vessel, while the client pays smaller amounts in advance or in instalments during the construction period, with the largest amount paid after the delivery. Warranties for financing the newly-built ships are normally provided to shippers by their commercial banks, whereas the shipyard obtains warranties from commercial banks and, under specific conditions, from the state (Hrvatska brodogradnja, 2015). In the present time of globalisation, this may affect the competitiveness of a shipyard in the global market, often resulting in dumping and disloyal competition, which is non-compliant with the postulates of the World Trade Organization (WTO). Japanese and South Korean shipyards are typical examples of the state-subsidy practice that has enabled them to become frontrunners in the global shipbuilding market (Author's calculations, 2017).

Coastal areas of the USA and developed countries of Europe have become inadequate for large-scale shipbuilding processes due to stringent environmental standards. It is well known that shipbuilding activities harmfully affect the environment. They require huge coastal areas, thus representing a non-economical option in the above mentioned countries, where the real-estate prices along the shorelines are rather high. This is why these areas are typically focused on more profitable industries, including housing, tourism, banking, and service activities in general (SEA Europe, 2017). Modern shipbuilding is an industry demanding a sophisticated know-how and high-skilled workforce. This requirement can be met only by highly developed and some of the developing economies (Razvoj, 2017).

\section{WORLD ORDER BOOK OF NEWBUILDINGS}

Today's largest shipyards are located in the Far East, in South Korea, China, and Japan. The leading shipyards take huge tracts of land in the vicinity of industrial zones outside city limits. Nine largest South Korean shipyards are situated in the same region. One of the reasons for the shipbuilding downsizing in the developed countries of the West is related to the environmental issues and the concept of sustainable development (Statista[b], 2016).

Figure 1 shows that in the first half of 2016 the world order book was in decline, compared to the same period the year before. Around 106 million compensated gross tons (CGT) or 5809 vessels were ordered. Their total value was approximately 290 billion US\$. The share of European shipyards amounted to 13 $\%$ or 38.8 billion US\$ of the ordered newbuildings, i.e. $8 \%$ CGT. These figures indicate that European shipyards produce more complex vessels, i.e. vessels with higher added value per tonnage (CGT) (Hrvatska brodogradnja, 2014).

The 2015 frontrunners in the number of contracts were the shipyards in China and Japan. However, in compensated gross tons (CGT), the leading shipyards were those in South Korea. In 2014, South Korean shipbuilding industry produced $33 \%$ of the global bulk carrier tonnage and $13 \%$ of the global container ship tonnage. In 2015, the output increased to $29 \%$ of all types of vessels. That year, the world order book contained a total of 1598 bulk carriers with around 130 million tdw, 978 tankers with about 93.6 million tdw, 436 container ships with around 42.5 million tdw, 201 LPG tankers with about 6.7 million tdw, and 159 LNG tankers with approximately 13.1 million tdw. (Hrvatska brodogradnja, 2015). 


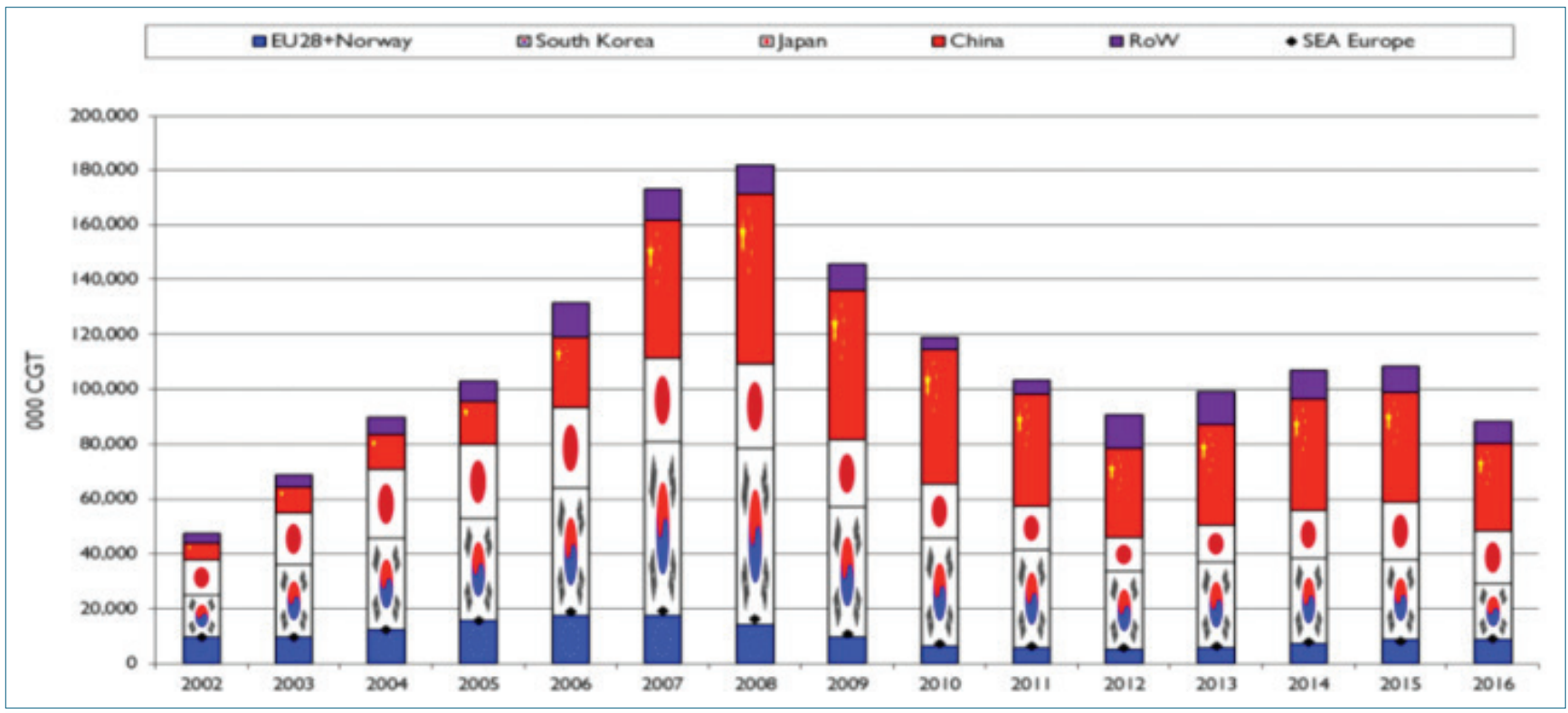

Figure 1.

World's book of orders by shipbuilding regions in the period 2002- 2016 (Razvoj, 2017).

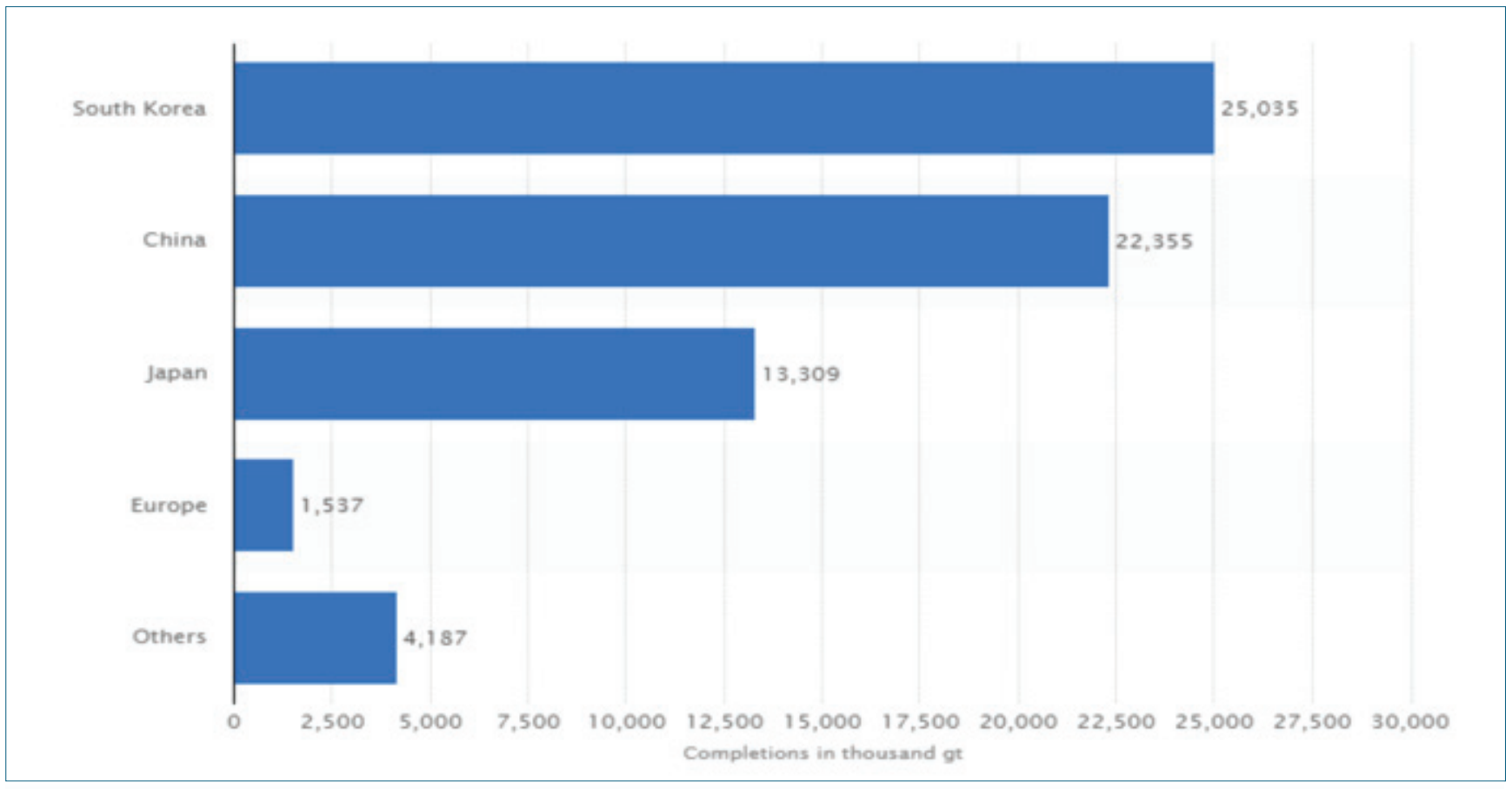

Figure 2.

Major shipbuilding countries in December 2016 (in thousand GT) (Statista[a], 2016). 
Figure 2 shows that, at the present time, the leading shipbuilding countries include South Korea, China and Japan. The year of 2016 experienced a slight decline in the book of world orders when compared to 2015. During the period 20142016 Japan's shipbuilding industry produced a larger number of vessels than South Korea. In terms of compensated gross tons (CGT), China ranked best in world order book with 31.7 M CGT, followed by South Korea (20.4 M CGT), Japan (19.2 M CGT) and the EU 28+Norway (8.6 M CGT). As for types of ships, tankers represent the principal item in the world order book (20\% CGT), followed by bulk carriers (18.9\%) and container ships (17.8\%). The shares of passenger ships and offshore vessels were $8.2 \%$ and $12.8 \%$, respectively (SEA Europe, 2017).

Figure 3 shows that South Korea and China had the largest order books in 2017. The market share of Europe increased to 19 $\%$, mainly due to construction of passenger vessels, cruise ships and off-shore vessels (SEA Europe, 2017).

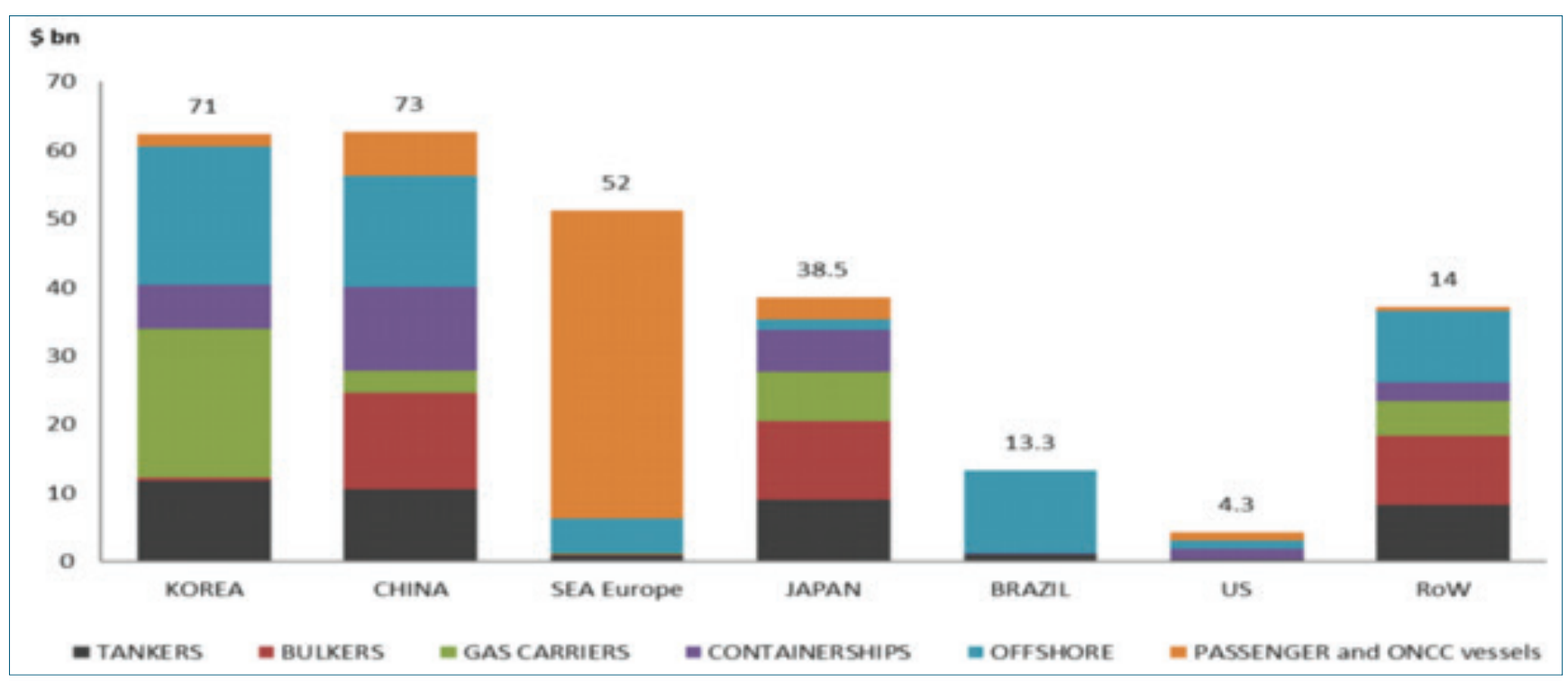

Figure 3.

Value of shipbuilding orders by areas (in billion US\$) in February 2017 (Razvoj, 2017).

March 2017 experienced the lowest level of shipbuilding orders since 2008, amounting to just 513 newly-built vessels. Compared to the same period in 2016, new-build orders were reduced by $70 \%$. However, the demand for passenger vessels and cruise ships increased, together with the record growth in LNG tonnage (304\%). In terms of CGT, the 2017 world order book had $36 \%$ of tankers, $22 \%$ passenger ships, $13 \%$ bulk carriers, $7 \%$ container ships and $4 \%$ offshore vessels. Compared to the early 2016, the major production drop in 2017 was in refrigeration ships (100\%), container and offshore tonnage (61\%), passenger vessels (13\%), RO-RO ships (12\%), and product and specialised tankers (1\%). Other types of tonnage experienced a notable growth in 2017, ranging from 24 to $304 \%$ (Hrvatska brodogradnja, 2017).

Figure 3 also demonstrates that, in early 2017, most of tankers, in terms of their value (CGT), were ordered at shipyards in South Korea, China and Japan. Likewise, it can be noticed that most of LNG carriers, in terms of their CGT, were ordered at shipyards in South Korea, Japan, the Rest of the World, with China ranked at the 4th place. The highest value of production of bulker tonnage was recorded at shipyards in China, Japan and the Rest of the World. It is obvious that South Korea does not participate significantly in building these simple and low-cost vessels. As far as container ships are concerned, most of their CGT was ordered in China, Japan and South, with the Rest of the World lagging behind. The largest global value of passengers, cruise and offshore tonnage was recorded in Europe, while the Chinese, Japanese and South Korean shipyards were lagging far behind.

In the following years, a reduced demand for offshore vessels may be expected because of the lowered oil prices and decreased activities in new investment, exploration and exploitation of hydrocarbons. Likewise, a reduced demand for LNG carriers may be expected due to their high percentage in the present order books. It is assumed that the demand for bulk carriers will remain stable, as will the demand for passenger and cruise tonnage (Poslovni.hr, 2017).

The analysis of the global market of the shipbuilding and the most relevant shipbuilding economies over the period of the next several years, results in the probable scenarios, as follows: 
1. South Korea: decrease in new-build LNG and offshore tonnage orders and the continuing demand for tankers and container ships,

2. China: continuing demand for bulk carriers, container ships, tankers, passenger vessels and cruise ships, and declining production of offshore vessels and LNG carriers,

3. Japan: continuing demand for bulk carriers, tankers, container ships, passenger vessels and cruise ships, and declining production of offshore vessels and LNG carriers,

4. Europe: continuing demand for passenger vessels and cruise ships, and drop in offshore tonnage orders, and

5. the Rest of the World: continuing demand for bulk carriers, tankers, container ships, and reduced LNG and offshore tonnage demand.

\section{QUANTIFICATION OF THE VARIABLES OF THE INFORMATION MODEL FOR GLOBAL SHIPBUILDING OVER THE PERIOD 2016-2020}

The variables selected for creating the information model for the global shipbuilding industry over the period 2016-2020 include: South Korea, China, Japan, Europe and the Rest of the World (RoW).

In terms of value of the newbuildings (in thousand CGT) and according to the world order books, this was the situation found in December 2016 (see Figure 2):

$\begin{array}{llll}\text { 1. South Korea: } & 25.0 & => & 38 \% \\ \text { 2. China: } & 22.4 & => & 34 \% \\ \text { 3. Japan: } & 13.0 & => & 20 \% \\ \text { 4. Europe: } & 1.5 & => & 2 \% \\ \text { 5. RoW: } & 4.2 & => & 6 \% \\ \text { Total: } & 66.1 & => & 100 \%\end{array}$

In terms of value of the newbuildings (in billion US\$) and according to the world order books, this was the situation found in February 2017 (see Figure 3):

$\begin{array}{llll}\text { 1. South Korea: } & 25.0 & => & 35 \% \\ \text { 2. China: } & 22.4 & => & 33 \% \\ \text { 3. Japan: } & 13.0 & => & 20 \% \\ \text { 4. Europe: } & 1.5 & => & 5 \% \\ \text { 5. RoW: } & 4.2 & => & 7 \% \\ \text { Total: } & 66.1 & => & 100 \%\end{array}$

Taking into the consideration the synergetic effect of the percentage obtained from the world order books, in terms of tonnage (CGT) and value (US\$) of the selected variables, the variable values for the year 2016 have been produced, as follows:

$\begin{array}{ll}\text { 1. South Korea: } & 33 \\ \text { 2. China: } & 31 \\ \text { 3. Japan: } & 20 \\ \text { 4. Europe: } & 7 \\ \text { 5. RoW: } & 9 \\ \text { Total: } & 100\end{array}$

Note: It is assumed that the total number of points for the selected variables will always be 100 for each year presented in Table 1. Each variable is quantified on the index scale from zero to 100 . On the basis of the mental and verbal insights into the scientific aspects of the global shipping market variables of the information model for the global shipbuilding, and on the basis of the study presented in the above paragraphs, the values of the variables are quantified for the years of 2018 and 2020, as shown in Table 1.

Table 1.

Points allocated to the variables of the information model for the global shipbuilding industry over the period 2016-2020.

Variables of the information model for the global shipbuilding industry over the period 2016-2020
Inputs

$\begin{array}{llll} & & & \text { (growth/fall) } \\ 2016 & 2018 & 2020 & 2016 / 20 \\ 33 & 32 & 30 & -3 \\ 31 & 32 & 34 & +3 \\ 20 & 21 & 22 & +2 \\ 7 & 7 & 6 & -1 \\ 9 & 8 & 8 & -1\end{array}$


The vector of the model growth is: $\Delta Y_{2020}\left[\begin{array}{r}-3 \\ +3 \\ +2 \\ -1 \\ -1\end{array}\right]$

The vector of the model's reciprocal values:

$\frac{1}{Y_{2020}}=\left(\frac{1}{30}, \frac{1}{34}, \frac{1}{22}, \frac{1}{6}, \frac{1}{8}\right)$

Matrix calculation:

$$
\Delta Y_{2020} x: \frac{1}{Y_{2020}}=>
$$

$$
R_{2020}\left[\begin{array}{ccccc}
\frac{-3}{30} & \frac{-3}{34} & \frac{-3}{22} & \frac{-3}{6} & \frac{-3}{8} \\
\frac{3}{30} & \frac{3}{34} & \frac{3}{22} & \frac{3}{6} & \frac{3}{8} \\
\frac{2}{30} & \frac{2}{34} & \frac{2}{22} & \frac{2}{6} & \frac{2}{8} \\
\frac{-1}{30} & \frac{-1}{34} & \frac{-1}{22} & \frac{-1}{6} & \frac{-1}{8} \\
\frac{-1}{30} & \frac{-1}{34} & \frac{-1}{22} & \frac{-1}{6} & \frac{-1}{8}
\end{array}\right]
$$

$R_{2020}\left[\begin{array}{rrrrr}-0,100 & -0,088 & -0,136 & -0,500 & -0,375 \\ 0,100 & 0,088 & 0,136 & 0,500 & 0,375 \\ 0,067 & 0,059 & 0,091 ; & 0,333 & 0,250 \\ -0,033 & -0,029 & -0,045 & -0,167 & -0,125 \\ -0,033 & -0,029 & -0,045 & -0,167 & -0,125\end{array}\right]$

The matrix calculation produces Table 2.

Table 2.

Values of the direct and indirect growth rates of the information model for the global shipbuilding industry over the period 2016-2020, on the index scale from 0 to 100.

\begin{tabular}{llllll} 
Model variables & 1 & 2 & 3 & 4 & 5 \\
\hline 1 & $-\mathbf{1 0 . 0}$ & -8.8 & -13.6 & -50.0 & -37.5 \\
\hline 2 & 10.0 & $\mathbf{8 . 8}$ & 13.6 & 50.0 & 37.5 \\
\hline 3 & 6.7 & 5.9 & $\mathbf{9 . 1}$ & 33.3 & 25.0 \\
\hline 4 & -3.3 & -2.9 & -4.5 & -16.7 & -12.5 \\
\hline 5 & -3.3 & -2.9 & -4.5 & -16.7 & -12.5 \\
\hline
\end{tabular}

Table 2 shows that the points (i.e. values) referring to the direct growth rates of the selected variables of the information model for the global shipbuilding over the period 2016-2020 are placed diagonally, ranging from +9.1 to -16.7 .

Due to limited space, this scientific paper does not discuss the values of indirect growth rates of the model variables.

There are notable differences between the values presented in the last column (Variations) of Table 1 and the values of the direct growth rates of the selected variables of the information model for the global shipbuilding over the period 2016-2020, shown diagonally in Table 2 . These disparities arise from the mutual influence (competition) of the largest shipbuilding nations in the global market for the period observed in the information model.

\section{CONCLUSION}

In this scientific study, for the first time in the process of analysing the world's modern shipbuilding industry, the growth matrix was used to produce the values of the selected variables, i.e. the direct growth rates of the information model for the global shipbuilding in the period 2016-2020. In addition to the matrix and modelling, the study has also involved a combination of scientific methods, including statistics, induction, deduction, description, comparative analysis and synthesis, with an aim of producing relevant results.

Japan will have the highest positive value of the information model's direct growth rates over the period 20162020, amounting to 9.1, whereas China will have the lowest positive value amounting to 8.8 . The highest negative value of 
the direct growth rates of the information model for the global shipbuilding in the period 2016-2020 will be experienced in Europe (16.7), while South Korea will have the lowest negative value of the growth rates, amounting to 10.0.

The research results indicate that, by 2020, South Korean shipbuilding industry will have experienced a decline in LNG and offshore tonnage orders. Over the same period, the demand for newly-built tankers and container ships remains stable. By the year 2020, Chinese shipyards will have experienced continuous demand for bulk carriers, container ships, tankers, passenger vessels and cruise ships, while the demand for offshore vessels and LNG ships will decrease.

There will be continuous demand for new bulk carriers, container ships, tankers, passenger vessels and cruise ships from Japanese shipyards by 2020, while the demand for offshore vessels and LNG ships will decrease. European shipyards will experience steady commissions for passenger vessels and cruise ships by 2020, while there will be fewer commissions of offshore vessels. Finally, in the rest of the world, there will be continuous demand for new-build bulk carriers, tankers and container ships by 2020, but commissions of new LNG carriers and offshore vessels will be reduced.

\section{REFERENCES:}

Author's Calculations according to Verband für Schiffbau und Meerestechnik e.V.: Jahresberichte, available at: http://www.vsm.de/de/service/publikation-undmedien/jahresberichte

Hrvatska brodogradnja - Jadranbrod d.d., (2014), Svjetsko brodograđevno tržište - studeni 2014, available at: http://hb.hr/wp-content/uploads/2015/01/HBjSvjetskotrziste.pdf
Hrvatska brodogradnja - Jadranbrod d.d., (2015), Svjetsko brodograđevno tržište studeni 2015, available at: http://hb.hr/wp-content/uploads/2015/11/HBj-Svjetskotrziste-2015-11.pdf

Hrvatska brodogradnja - Jadranbrod d.d., (2017), Svjetsko brodograđevno tržište - lipanj 2017, available at: http://hb.hr/wp-content/uploads/2017/07/HBj-Svjetskotrziste-2017-06.pdf

Ivanković, J., Ljubenkov, B., Žiha, K., (2009), Pregled brodogradnje trgovačkih brodova u svijetu, Brodogradnja 60(1), available at: https://hrcak.srce.hr/index. php?show=clanak\&id_clanak_jezik $=54872$

Kersan-Škabić, L., (2009), Brodogradnja u Europskoj Uniji i Hrvatskoj, realnost i izazovi, Ekonomska misao i praksa 18(2), available at: https://hrcak.srce.hr/file/74933

Hrvatska enciklopedija, (2017), Leksikografski zavod Miroslav Krleža, available at: http://www.enciklopedija.hr/Natuknica.aspx?ID=9645

Mitrović, F., (2007), Ekonomika pomorstva, Split: Faculty of Maritime Studies.

Poslovni.hr: U svijetu 513 novih gradnji, kod nas svega sedam, (2017), available at: http://bur.com.hr/u-svijetu-513-novih-gradnji-kod-nas-svega-sedam/

SEA Europe, Shipyards \& Maritime Equipment Association, (2017), SEA Europe Shipbuilding Market Monitoring Report No. 42, available at: https:// maritimetechnology.nl/media/ SEA-MM-REPORT-42-FINAL.pdf

Statista[a], (2016), Largest shipbuilding nations in 2016, based on completions in gross tonnage (in 1,000s), available at: https://www.statista.com/statistics/263895/ shipbuilding-nations-worldwide-by-cgt/

Statista[b]: (2016), Leading shipbuilding companies worldwide as of March 2016, by orderbook value (in billion U.S. dollars), available at: https://www.statista.com/ statistics/257865/leading-shipbuilding-companiesworldwide-based-on-volume/

Razvoj i prostorni raspored brodogradnje u svijetu, (2017), Zadar: Sveučilište u Zadru, available at: http://www.unizd.hr/Portals/1/nastmat/pomgeograf/ Brodogradnja.pdf

Šimičić, B., (1972), Brodogradilište, Pomorska enciklopedija, Zagreb: Jugoslavenski leksikografski zavod. 